\title{
白血球溶解現象飞関する研究
}

第二篇 人血清感作家鬼に拈ける観察

関西医科大学第一内科教室（指導 大久保滉教授）

今 西 二 三 男

\section{Studies on the Lysis-Phenomenon of Leucocytes}

\section{Rep. II. Observations on the Sensitized Rabbits by Human Serum.}

\section{Fumio Imanishi}

Department of 1st Internal Medicine, Kansai Medical School

(Supervised by Prof. H. Ôkubo, M.D.)

The rabbits were sensitized by $1.0 \mathrm{cc}$ of human serum given intravenously every other day three times. Two weeks after sensitization, precipitation titer of rabbit serum was quantitatively measured in vitro and morphologically observed under phase-contrastmicroscope.

Furtherly, existence of antigen specificity was investigated by comparing the cases added with human serum to those added with ovo-albumin to the human-serum-sensitized rabbits.

1) When corresponding antigen was added to the peripheral blood of human-serumsensitized rabbit in vitro, rate of leucocytic decrease was recognized to be increased, morphologically lysed, degenerated cells were increased in comparison with those of pre-sensitization.

2) Neutrophiles acted main part of role in the phenomenon of leucolysis, each neutrophile presented difference in reaction, so that there recognized various stages from nonaffected ones to lysed ones.

3) The cells to meet lysis presented distinct Brown movement of granules, and swelling of nucleus and cytoplasm, then destruction of cytoplasmic membrane was followed with the destruction of nucleic membrane. Such a course was completed mostly in a few minutes, and in ten to fifteen minutes at the latest.

In the degenerating cells, there is also the difference of reaction, and required time is not constant, because of their grade of reaction.

4) No certain parallel relationship could be recognized between precipitating titer and the phenomenon of leucolysis.

5) In this experiment, antigen specificity was also recognized.

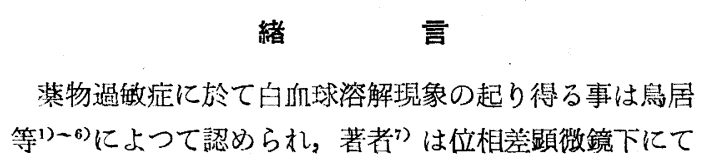

過敏症患者末稍血に当該薬物加被験者 Plasma を接触せ しも，その形態的変化を観察し，好中球が崩壊乃至種々 の程度の変性を示すことを認め, 白血球溶解現象の起り 得る事を知り得，てれについては第一篇で述べた。 
実験的アレルギーの末稍血液像を溗察したのはBiedl, $\mathrm{Kraus}^{\mathrm{s})}$ を以て咥短とし，彼は馬血清を用いアナフィ； キシーショックの際一過性の白血球減少（特に顆粒球） が起る事を認めて以来 Dean, Webb9)，Kinsell et al ${ }^{10)}$ 等により認められている.

生体外に於て対応抗原を加えた実験では Waksman ${ }^{11)}$ が即白アルブミン，牛とグロブリンを用いて家鬼を感作 し白血球溶解現象を認め，乙れを起す抗体（Lytic antibody）は沈降性抗体とは無関係であるとして居る．石 田 ${ }^{12)}$ は諸種ワクチンを用いて同様 in vitro で白血球 溶解現象を認め抗原特異性のある事を述べて居るが， Webb ${ }^{19)}$ は馬血清で感作した犬の血液に試験管内で馬血

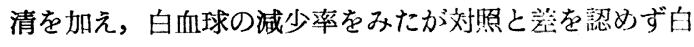
血球の溶解は起らないとして居る.

本篇に於て著者は実験的に人血清を用いて家鬼を留作 し，感作前後に於て白血球娍少率を算定すると同時に位 相差顕微鏡下にてその形態的变化を観察した，又愿作前 後に沈降価を測定し白血球溶解現象との平行関係をしら へ，抗原特異性の有無を検索し 知見を得たので報管す る.

\section{実験材料及び実呀方法}

\section{I. 実験動物}

実験動物には健康家鬼 $2.5 \mathrm{~kg}$ 前後のものを選び予め一 定期間，一定食慨により飼育し，之を実験に使用した。

I. 実験方法

a) 感作方法

感作には新鮮同一人健康者血清を使用し，1.0 c c 在陑 日 3 回静注し，2週後沈降価を測定，1迴閒内にド血球 溶解現象を検查した。

b ) 実験術式

孙伹液凝固防止の為に0.1cc（1 mg）へパリンを入 れた注射器で心穿刺を行い得られた血液 $5.5 \mathrm{cc}$ に $12 \%$ 葡 萄糖0.5cc を加え静汃に50回振湜混和，乙の5.0cc に新 鮮人血清（感作に使用したものと同一人血清） $0.25 \mathrm{cc}$ を 加え同様混和後，小試験管に分注，管口を封蠟し37.0师 畉器中に質え 5 分，1時間，2 時間 3 時間後に 1 本宛之 を取り出し実験に供した，尚白血球の沈漖凝集を防引゙為 一定時間每に静かに振䔽した。

白血球の算定には検定した同一メランジュールを用い 150回振燳し，その 4 5 滴目を Bürker- Türk 氏計算 器にて算定した。 なお抗原混和前を前值として人血清稀 釈分を換算した．形態的観察には第一篇既述の方法によ。 り位相差顕微鏡を用いて行い，家乘血清 $2.5 \mathrm{cc}$ に人血清 $0.25 \mathrm{cc}$ (家鬼血液の血清外成分の容謮在約 $1 / 2$ と淩兄前 記白血球算定時の人血清濃度に近くした） ）を混和した
あのを注入した。

\section{実 験 成 綪}

正常家鬼に於ても白血球隇少率に幾分の個体差位を認 めたので，同一家兔感作前を対照とし感作前すでに減少 率大なるものは除外した。

I. 白血球数の変化

実験家鬼 5 羽の㷂作前後の白血球数の平均值は第 I 図 に示す如くである，即ち白血球は感作前に於ては緩徐な 濑減傾向を示して居るに対し感作後に於ては 5 分後にす でに6590より6290となり，1 時間值では5890に減少し以 後は 2 時間， 3 時間と漸娍して居る.

偽㶩酸球, 淋巴球の絶対值は血液塗抹標本を作成し, その\%上り算定した。（血液像算定に対し種別不明のも のは，不明細胞とし，又，顆䊉球を思わしむるも变性の 為明らかでないものは不明（顆粒球？）として夫々\%に 算入した.）

偽好酸球は白血球数の減少と其に娍少を恋めた，即ち 第 I 図に示す如く感作後に於ては 5 分後，すでに城少を

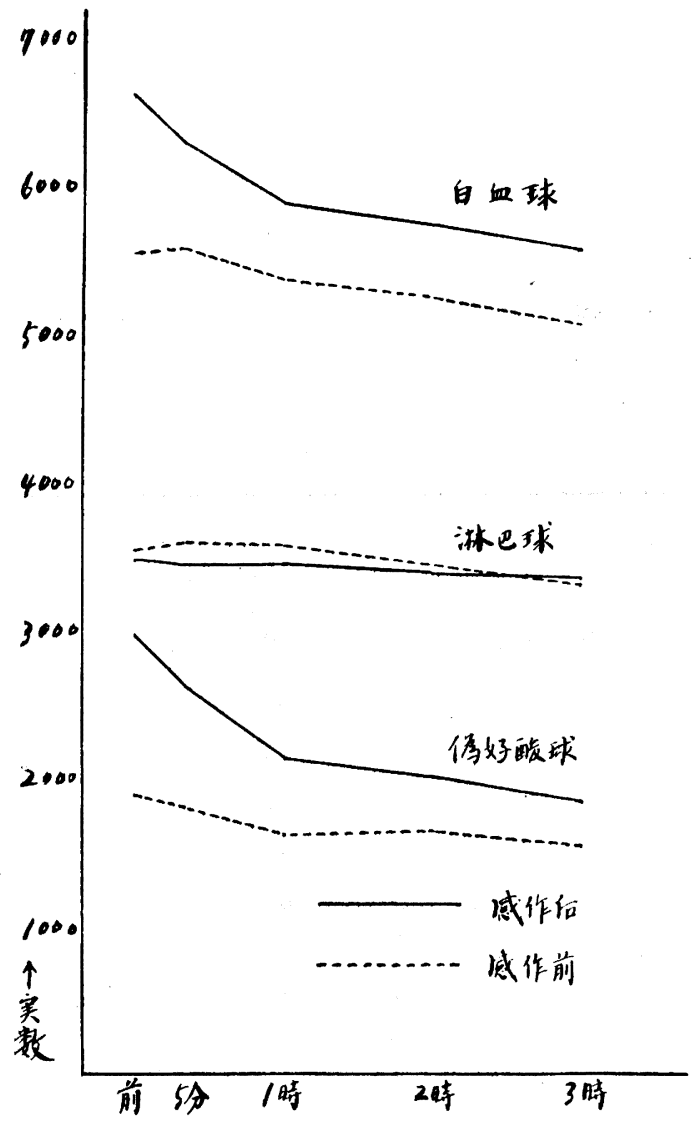

第 1 目自血球の種別の変動 ( 5 例平均) 抗原添加実験（人血清感作家鬼） 

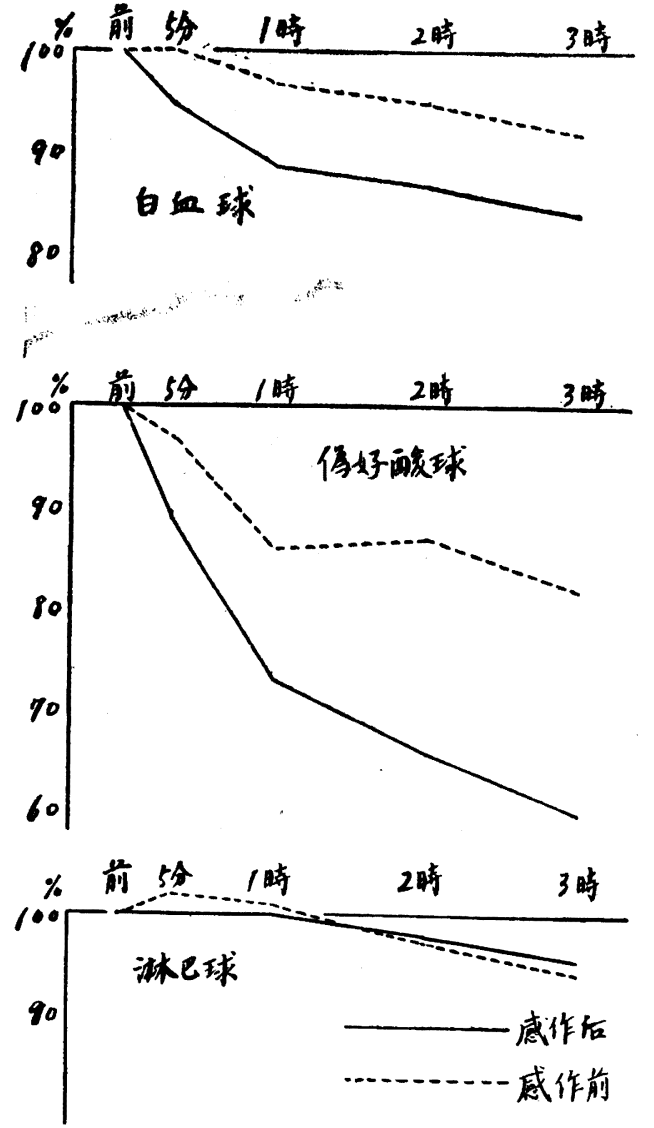

第 2 図自血球種別の時間的変化悴 ( 5 例平均) 扰原添加実験（人血清感作家鬼）
認め，1 時間では2940より2150と減少し以後 2 時間 3 時 間と漸減して居るが感作前に於ては綬徐な濑減傾问をと つて居るにすぎない。

淋巴球は感作前後とも著差を恋めず，又あまり変動を 認めなかつた。

单球，好酸球，好塩基球は数が少なくその差を記載す るに至らなかつた。

向血球数, 偽好酸球数, 淋巴球数の前值を $100 \%$ とし, そ の時間的変化率をみると第 2 図の如くである．即ち白血 球数, 偽好酸球の減少は感作後に於ては著明であり,淋巴 球には著明な差を認め得ない事を明らかに示している。

以上 5 例平均值について述心゙たのであるが，その 1 例 を表示すれば第 I 表（家鬼 No. F）の如くであり，感作 前に於ては放置してああまり変化を受けて居ないが，感 作後は白血球の減少が著明でその主体が偽好酸球である のを示して居る.

I. 位相差顕微鏡による形態的観察

偽好酸球を主体としてその形態的観察を行つた：

本実験に於ても第 I 篇既述の如き変化と略々同様の形 態的変化を認めた．即ち偽好酸球は個々に反応の強弱が あり，崩壊に至るむの，影響を受けるも崔壊に至らない むの，又殁んど影響を受けないと思われるもの迄種々の 様相を呈した。

著明なる反応を呈し崩壊に至る細胞は円形化し，次い で原形貿の膨化，顆粒の著明なブラウン運動を来し，核 は一過性に縮少するが次いで膨化し明らかとなり，更に 膨化は進み遂には核は全く無構造化し融解を思はしむる

第 1 表 家鬼No. F $の$ 血液像の時間的変化 抗原添加実験（人血清感作家鬼）

\begin{tabular}{|c|c|c|c|c|c|c|c|c|c|c|c|c|}
\hline \multicolumn{8}{|c|}{ 感 作 前 沈降価 0 倍 } & \multicolumn{3}{|c|}{ 感作後 } & \multicolumn{2}{|c|}{$\begin{array}{l}2048 \text { 倍 (士) } \\
4096 \text { 倍 }( \pm)\end{array}$} \\
\hline 時 & & 間 & 前 & 5 分 & 1 時 & 2 時 & 3 時 & 前 & 5 分 & 1 時 & 2 時 & 3 時 \\
\hline 白 & 血 球 & 数 & 5100 & 5200 & 5000 & 4900 & 4900 & 5700 & 5500 & 5300 & 5100 & 5100 \\
\hline 偽 & 好 酸 & 球 & 33.5 & 33.0 & 33.0 & 33.0 & 32.5 & 32.5 & 30.0 & 27.0 & 26.0 & 25.5 \\
\hline 絶 & 対 & 值 & 1710 & 1710 & 1650 & 1610 & 1590 & 1850 & 1650 & 1430 & 1320 & 1300 \\
\hline 偽 & 桿 & 核 & 13.5 & 13.5 & 15.5 & 14.5 & 12.5 & 15.5 & 17.5 & 17.5 & 10.5 & 8.0 \\
\hline 好 & 分 & I & 13.0 & 13.5 & 15.0 & 14.5 & 13.0 & 12.0 & 8.5 & 7.5 & 11.0 & 12.0 \\
\hline 酸 & 節 & II & 5.5 & 6.0 & 2.5 & 3.5 & 6.5 & 4.5 & 4.0 & 2.0 & 4.5 & 5.5 \\
\hline 球 & 核 & IV & 1.5 & 0 & 0 & 0.5 & 0.5 & 0.5 & 0 & 0 & 0 & 0 \\
\hline 淋 & 巴 & 球 & 62.5 & 63.0 & 63.5 & 63.0 & 62.5 & 63.0 & 65.5 & 67.0 & 68.5 & 69.5 \\
\hline 絶 & 対 & 值 & 3190 & 3270 & 3170 & 3080 & 3060 & 3590 & 3590 & 3550 & 3490 & 3540 \\
\hline 淋 & 大 & 淋 & 2.5 & 3.5 & 3.0 & 3.0 & 4.5 & 1.0 & 1.0 & 1.0 & 0.5 & 0.5 \\
\hline 球 & 小 & 淋 & 60.0 & 59.5 & 60.5 & 60.0 & 58.0 & 62.0 & 64.5 & 66.0 & 68.0 & 69.0 \\
\hline
\end{tabular}




\begin{tabular}{|c|c|c|c|c|c|c|c|c|c|c|c|}
\hline 酸 & 球 & 0.5 & 1.0 & $0^{\circ}$ & 0 & 0 & 0 & 0 & 0 & 0 & 0 \\
\hline 好 㙁 基 & 球 & 0.5 & 1.0 & 0 & 0.5 & 0 & 1.0 & 1.0 & 1.5 & 1.0 & 0.5 \\
\hline 紧 & 球 & 1.5 & 1.0 & 1.0 & 1.0 & 1.5 & 1.5 & 1.0 & 1.0 & 0.5 & 1.0 \\
\hline 不明 (顆粒球 & ?) & 0.5 & 1.0 & 1.0 & 1.0 & 1.5 & 1.0 & 1.0 & 2.5 & 3.0 & 2.5 \\
\hline 不 & 明 & 1.0 & 1.0 & 1.5 & 1.5 & 2.0 & 1.0 & 1.5 & 1.0 & 1.0 & 2.0 \\
\hline
\end{tabular}

第 2 表 位相差像による形態的分類（\%) 5 例平均（2 時間後） 抗原添加実験（人血清感作家鬼）

\begin{tabular}{|c|c|c|c|c|c|c|}
\hline & 样 & 型 & 感作前 & 計 & 感作後 & 計 \\
\hline $\begin{array}{l}\text { 溶 細 } \\
\text { 解 } \\
\text { 変 } \\
\text { 性 胞 }\end{array}$ & $\begin{array}{l}\text { 細胞崩壊を思わしむるも明かならざるもの } \\
\text { 細胞崩買の形態残存 } \\
\text { 紐胞内容の無構造化又は核融解 } \\
\text { 核全く無構造化，原形質胵化 }\end{array}$ & $\begin{array}{l}\text { I } \\
\text { I } \\
\text { II } \\
\text { IV }\end{array}$ & $\begin{array}{l}1.6 \\
0 \\
0.2 \\
1.0\end{array}$ & 2.8 & $\begin{array}{l}1.8 \\
1.8 \\
1.4 \\
5.2\end{array}$ & 10.2 \\
\hline $\begin{array}{l}\text { 被 細 } \\
\text { 影 } \\
\text { 㡍 胞 }\end{array}$ & $\begin{array}{l}\text { 粗大顆粒, 核無構造化, 原形質䂑化 } \\
\text { 異常運動 } \\
\text { 円形静止 }\end{array}$ & $\begin{array}{l}\text { V } \\
\text { VI } \\
\text { VII }\end{array}$ & $\begin{array}{l}2.2 \\
0 \\
9.6\end{array}$ & 11.8 & $\begin{array}{r}7.4 \\
1.8 \\
29.2\end{array}$ & 38.4 \\
\hline $\begin{array}{l}\text { 正影き } \\
\text { 常響も } \\
\text { 爻少も } \\
\text { はなの }\end{array}$ & $\begin{array}{l}\text { 運動性の減退，殆んど静止 } \\
\text { 運動性を認むるもの } \\
\text { 遊走紐胞 }\end{array}$ & $\begin{array}{l}\text { VH } \\
\mathrm{X} \\
\mathrm{X}\end{array}$ & $\begin{array}{r}29.6 \\
46.8 \\
9.0\end{array}$ & 85.4 & $\begin{array}{r}42.4 \\
8.8 \\
0.2\end{array}$ & 51.4 \\
\hline
\end{tabular}

に至り，原形貿の膨化にともない遂には細胞膜の破流を 来し細胞形骸となるに至る.

その他，核及び原形䆩の膨化溶解を来し多んど細胞膜

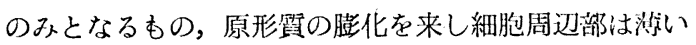
無構造な膜様となり，又漱次縮少し核の無構造化，顆粒 の粗大化を来し変性し去るもの，父初妨り㱠んど変化 を受けないと思われるものまで認めた。

崩壊に至る細胞は主に数分内で崩壊し去り遅くとも約 10 〜15分で完了し以後に於ては，その区応の強弱により変 性化する時間は個々に於て差を認める屯，著明な崩站に まで至るものを認め得なかつた。

本実験中淋巴球には明らかな崩壊を認め得なかつた。

一部軽度の原形質の膨化を来して居るものを認めたのみ である。

偽好酸球を崩垶変性程度, 活動力, 遊走力等により次 の如く分類し各例につき感作前後の形態的変化の差をし らハシた.

I 型 紏胞崩壊を思わしむるむ明らかな

$$
\text { らざるもの }
$$

I型 細胞崩壊の形態残存

I型 細胞内容の無構造化又は核融解

IV型 核全く無構造化，原形質膨化

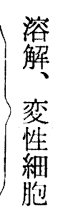

V 型 粗大顆粒，核無構造化，原形質膨化 被胞

V型 異常運動

VI型田形静止

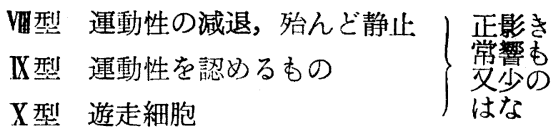

この如く分類した実験家鬼 5 羽の感作前後に於ける 2 時間後の平均\%は第 2 表の如くであり，感作後に於て溶 解，変性細胞及び被影響細胞の増加を認めた。

第 I 表（家鬼No. F ）の例に於ける偽好酸球の变性度 による分類は第 3 表の如くであり, 感作後に於ける城少 率の増大に伴い溶解変性細胞, 被影響細胞の増加を認め ている.

第 3 表 位相差像による形態的分類 (\%) 家鬼 No. F ( 2 時間後) 抗原添加実験（人血清感作家鬼）

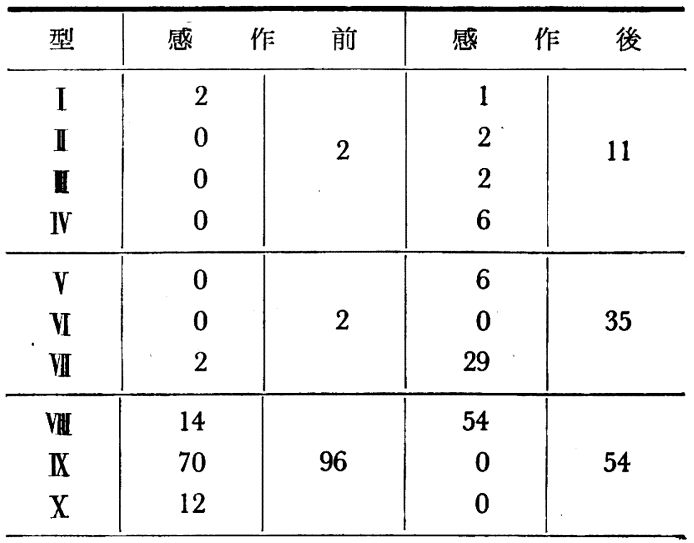

註：型分類は第 2 表と同じ 
I. 沈降価と減少率との関保

沈降価と減少率との間の平行関係をみる為に感作前後

に於てこの沈降価をしらべた。

沈降価測定には抗原稀彩に上る雷畳法を行つた。

減少率は感作前後に於ける減少率の差を求め, 減少率
差として沈降価との関係をみた。

白血球数の減少率差を出すと共にその主体ななす為好 酸球についても同様に行つた。

娍少率差の算定は次式の如く行つた。

即ちマイナスの数值の大なる程感作後の減少が感作前

白血球数減少率差 $=\left\{1-\right.$ (感作前) $\left.\frac{\text { 各時間白血球数 }}{\text { 前值白血球数 }}\right\} \times 100-\left\{1-\right.$ (感作後) $\left.\frac{\text { 各時間白血球数 }}{\text { 前值白血球数 }}\right\} \times 100$

偽好酸球数減少率差 $=\left\{1-\right.$ (感作前) $\left.\frac{\text { 各時間偽好酸球絶対值 }}{\text { 前値偽好酸球絶対值 }}\right\} \times 100$ 列

$$
-\left\{1-\text { (感作後) } \frac{\text { 各時間偽好酸球絶対值 }}{\text { 前值偽好酸球絶対值 }}\right\} \times 100
$$

に比し著明である事を表わす様になる。

実験家鬼 5 羽を沈降価の大なる順に表示すると第 4 表 の如くであり，各時間の減少率差をみると各時間共，沈

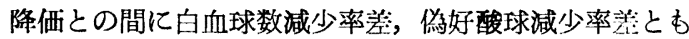
明らかな一定関係を見出し得なかつた。

第 4 表 沈降価と減少率（感作前後に於ける差） との関係

白 血球

\begin{tabular}{|c|c|c|c|c|c|c|}
\hline 家鬼 No. & 沈降価 & 前 & 5 分 & 1 時 & 2 時 & 3 時 \\
\hline $\mathrm{E}$ & 4096 & 0 & 0 & -2 & -6 & -6 \\
\hline F & $\begin{array}{l}2048(+) \\
4096( \pm)\end{array}$ & 0 & -2 & -5 & -6 & -6 \\
\hline $\mathrm{D}$ & $\begin{array}{l}2048(+) \\
4096( \pm)\end{array}$ & 0 & -8 & -16 & -12 & -12 \\
\hline B & 1024 & 0 & -4 & -10 & -12 & -13 \\
\hline A & 256 & 0 & +1 & -2 & +3 & -3 \\
\hline
\end{tabular}

偽好酸球

\begin{tabular}{c|l|l|l|r|r|r|r}
\hline 家象 No. & 時降価 & 前 & 5 分 & 1 時 & 2 時 & 3 時 \\
\hline E & 4096 & 0 & +1 & -8 & -15 & -26 \\
F & $2048(+)$ & 0 & -11 & -19 & -23 & -24 \\
& $4096( \pm)$ & & & & & \\
D & $2048(+)$ & 0 & -12 & -38 & -33 & -31 \\
B & $4096( \pm)$ & 1024 & 0 & -12 & -19 & -25 & -21 \\
A & 256 & 0 & -6 & +6 & -9 & -9 \\
\hline
\end{tabular}

N. 抗原特異性について

同様人血清感作家鬼末梢血を用い抗原特異性を㭘討し た。 但し血液は倍量採取して 2 分し一方に人血清，対照 として人血清蛋白\%と同\%の卵白アルブミン生食溶没を 添加した。感作家科については，人血清と卵的アルブミ ンとの間に教異を認ぬ得た。

向血球数，偽好酸球，淋巴球についてみると白血球 数、偽好酸球は第 3 図に示す如く，その減少摔は人血清
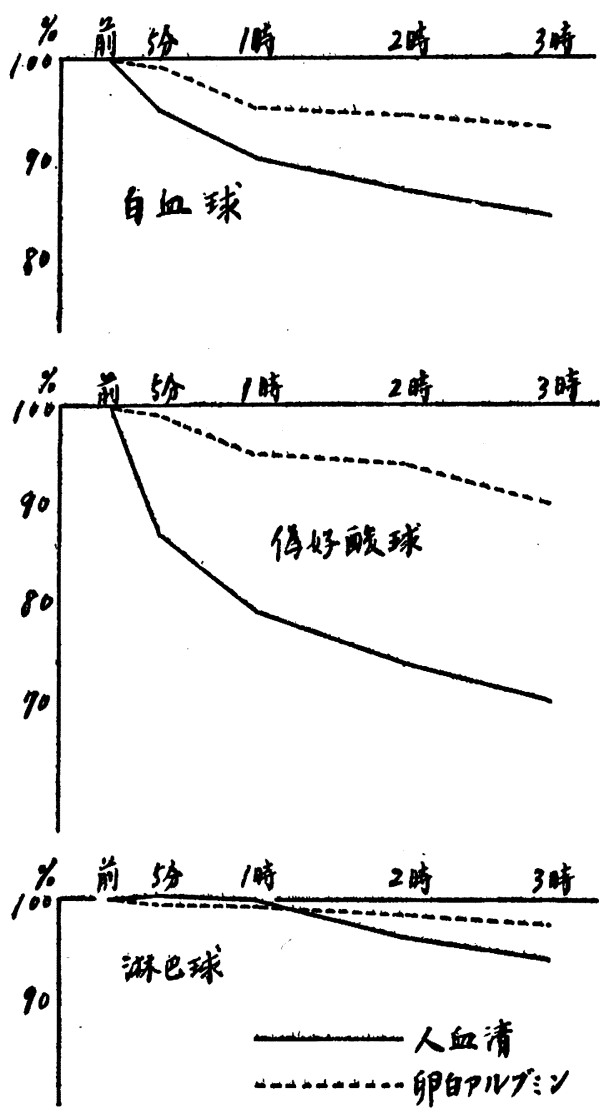

第 3 図白血球種别の時間的変化率 抗原特異性に関する実験

に著明であり，卵白アルブミンでは著明な城少を示さな かつた．又淋巴球では著明な変動を認め得ず明らかな觉 を認め得なかつた。

前述と同様方法による，位相差像におけ西形態的分数 では第 5 表の如く，形態的にも望異を認多得た。

非感作家躳に於ては人血清と卵门1アルブミンとの間に 差異を認め得なかつた。 
第 5 表 位相差像に上る形態的分類 (\%) 抗原特異性に閏する実験

\begin{tabular}{c|r|r|r|r}
\hline 型 & \multicolumn{1}{|c|}{ 人 } & 血 & 清 & \multicolumn{2}{|c}{ 卵白アルブミン } \\
\hline I & 2 & & 1 & \\
I & 2 & 10 & 0 & 2 \\
I & 1 & & 0 & \\
IV & 5 & & 1 & \\
\hline V & 12 & & 5 & \\
V & 6 & 37 & 0 & 15 \\
VII & 19 & & 10 & \\
\hline VII & 41 & & 39 & \\
X & 12 & 53 & 43 & 82 \\
X & 0 & & 0 & \\
\hline
\end{tabular}

拄：型分類は第 2 表と同じ

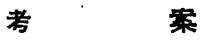

実験的アナフィラキシー・ショックの末梢血莅像を観

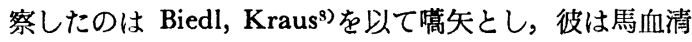
を用いアナフィラキシー・ショックの際一過性の白血球

（特に顆粒球）減少の起る事を認めて以来 Dean, Webb9)，Kinsell, et al ${ }^{10)}$ 等により認められている.

この顆粒球減少の機序について，従来分布の变化，即 ち白血球が体内臟器に集まるために末梢血から姿を消す といら説が有力である。実際にアナフィラキシーショッ ク時に末梢血中白血球の城少に比し内藏（特に肺）に白 血球，殊に顆粒球の抑留，集積を $\mathrm{Webb}^{13)}$ ，让井 ${ }^{14)}$ ，岳 碩 ${ }^{15)}$ 等により認もられて居り，乙の体内分布の変化がシ ヨック時の末椎血中白血球の減少の主因と考えられてい る. Miescher ${ }^{18)}$ 等は実験的アナフィラキシーショックに 於ける自血球減少について，抗原抗体結合物が白血球を 凝集させ，てれが内藏に抑留されるという説を出してい る。この様な白血球凝集, 分布異常の他に白血球溶解現象 が起るか否かについては意見の一致をみない. Webb' は馬血清で感作した犬の血腋に試験管内で馬血清を加え 白血球の減少率をみたが対照と差を認めず，白血球溶解 は起らないとし，Moeschlin ${ }^{17)}$ は抗白血球血清を用いて あ白血球の凝集は起るが溶解はしないとしている。

然し一方 Waksman'11)卵白アルブミン，牛 リンで感作した家鬼を用い in vitro で抗原抗体反応に 上り, 白血球溶解現象が起るととを証明して居る. 又, 石田 ${ }^{19)}$ は諸種ワクチンで感作した家鬼血液に試験管内で 抗原を加え白血球の減少を認めて居る。

Favour ${ }^{18)}$ らは結核動物あるいは患者の白血球にッべ ルクリンを添加すると白血球の溶解を起す事を認め，本 邦に於ても中山等 ${ }^{19)} ， 川\left(\right.$ 原 $^{20)}$ も机を追試し碓認してい
る. この現象は鳥居》によりペニシリン過做症に成用さ れ，ペニシリン湀加により白血球溶解現象の起るのを或

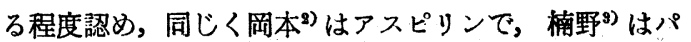
ス, 大久保 ${ }^{(5)}$ ，川原 ${ }^{(6)}$ は多数の薬物過敏症に於てての現 象を認めて居る。

この白血球溶解現象について先人諸家の研究術式は大 同小異で血液又は白血球浮遊液に抗原を加え $37^{\circ} \mathrm{C}$ 亿保温 し, 一定時間後, 細胞数の減少を算定し, 血液塗抹標本 について変性像を追究しているものが多く，その変性過 程を追跡して居る報告は Besis ${ }^{21}$ が人血球感作家鬼血清 を用いて位相美顕微鏡で観察し溶解現象を認め，その現 象は抗血清接触後数秒にして著明な反応を呈し始める事， を認め，その過程を述へて居り，小延 ${ }^{22)}$ は大好中球を顆 䊉，核，工夕ノ一ル沈降性胞体成分に分劃し，各々家鬼 に注射し抗血清を得，それぞれを $\mathbf{a}$ 血清， b 血清， c 血 清とし同様位相差顕微鏡で観察し, a 血清に於て著明な 崩境を10分以内に来たすと述べて居るが，a 血清を末枌 血と混和後標本を作成したので検鏡時既に相当膨化した 後が多く初期の状態は不明であると述へている. その他 にこの種の報告をみない。乙れらはいづれも好中球，又 は好中球顆䊉を用いて作成された抗血清を用いたもので あり，好中球に直接関係をむたない抗原を用いてそも率 壊変性過程を追跡した報告をみない。

著者は先人諸家の方法により，その減少率を算出する と同時に位相差顕微鏡でその崩壊変性過程を検索し白血 球溶解現象をしらべた。

第 I 篇》に於て好中球の崩壊が短時間に行われるのを 知つたので，本实験に於ては抗原を加える前を前值とし 抗原添加に上る稀彩分を換算し, 抗原添加後 5 分, 1 時 間， 2 時間， 3 時間とその減少率を算定し，感作後の血 液に於て白血球の減少率の大なるを認めた。

白血球溶解現象に於て白血球減少の主体をなすおのは Waksman $^{11)}$ ，石田 ${ }^{12)}$ ，(家鬼感作実験）Favour ${ }^{18)}$ ，川

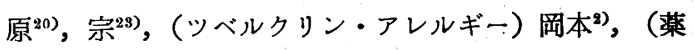
物過敏症）等いづれあ好中球である事を認めて居る. 著 者》も薬物過敏症に於て同様のととを認めたととは第 1 篇に述べた所である。

好中球が特に減少するてとについては好中球（偽好酸 球）は感作前に於ても放置により比較的集合し易い㑯向 がある如くであり，感作後に於てはその傾向が著明とな る為に，算定の場合変動が強くなる可能性をも考えなけ ればならないが，著者は本実験に於て形態的変化に於て 屯偽好酸球に崩壊変性するものが多く，淋巴球には殆ん どてれをみない事より好中球 (偽好酸球) が白血球溶解 現象の主体をなすととは裹附けされたすのと考える.

上述の様に著者の観察では細胞の崩壊は殆んど数分以 
内に完了し，崩壊に至らぬ細胞は種々の反応差を呈し， その程度により変性細胞化する時間む一定でない，本実 験の白血球減少率の算定で，漉和 5 分にすでに減少を認 めたのは崩壊に至る細胞がすでに 5 分後には崩壊し去つ た為に白血球数の娍少として表われ，その後著明変性細 胞が算定による器械的刺㦸などにより，崩壊する為に一 時間值の減少として表われ，以後は变性の軽度のむのに 一部自然退行性変性む加わり, 器械的刺㦸と相俟つて漸 減するすのかと考元られる. 故に白血球溶解現象の減少 率算定に於て前值のとり方が問題であり, 抗原混和直後 を前值とする方法は直後に強い変性を受け崩壊する細胞 数を見逃す可能性がある。

Waksman ${ }^{11)}$ は抗血清の白血球溶解力はこの沈降性抗 体量に関係しない. 抗原を少量づつ添加して沈降性抗体 を沈降させ除去しても溶解力は減じないと報告して居 る.

本実験に於て感作前後の沈降価を測定し，感作前後の 堿少率差 とを比較したが，白血球数，偽好酸球数共 5 分, 1 時間, 2 時間, 3 時間, 各時間の減少率差と沈降. 価との間に一定関係を認ぬ得ず，沈降価と溶解現象との 間に一定関係はないすのと考えられる。

楽物過敏症において抗原特異性のある事は臨㦿的にす でに知られて居るとてろであり，アレルゲンの診断に試 験投与による，一過性の未梢白血球の減少を指標とする 方法がかねてより行われ (Widal ${ }^{24)}$, Vaugham ${ }^{25)}$, Ro$\mathrm{st}^{26)}$, ) て居り，大久保占むその変動（特に減少）を認》 て居る.

白血球溶解現象に於てあ石田 ${ }^{12}$ は細菌抗原について抗 原特異性を認め, 下条) はペニシリン過敏症にペニシリ ンで特異的な反応を認めているが，同時にストレプトマ イシン, プロカインを附加した場合に若干の白血球溶解 を認めて，てれが非特異的現象であるか又ペニシリン過 敏症患者が同時にストレプトマイシン，プロカイン等に 対しても多少過敏状態になつているのかは明らかでない として居る.

著者は本実験に於て抗原特異性の検索を屯同時に行つ た. 人血清感作家鬼に卵白アルブミンを対照として対応 抗原との間に明らかな差異を認め得た. 即ち対応抗原添 加では著明な白血球減少を認めたが，卵白アルブミンで は感作前の白血球减少率と略々同様であり，又形態的に あ感作前のそれと類似していた。 ての場合対照として 用いるものは抗原たり得る性質のものでなければなら ず，卵白アルブミンは Waksman ${ }^{11)}$ が抗原として使用し 溶解現象をみとめて居るむのであり，本実験の対照抗原 として使用し得るすのと考える.

\section{結 䜽}

1.人血清愿作家鬼末梢血に対応抗原を作用せしめ, その減少率, 形態的変化より白血球溶解現象の起り得る 事を認めた。

2. 白血球溶解現象の主体をなすものは偽好酸球であ り，偽好酸球個々に於てそれぞれ反応差を呈し，崩壊に 至るものから殆んど影響を受けないと思われるものまで ある事を認めた。

3. 崩壊に至る細胞は主に数分内で崩壊し去り遅くと あ10〜15分内に完了した.

変性化する細胞に於てもそれぞれ反応差があり，その 時間はその反応の程度により一定ではない.

4. 沈降価と白血球溶解現象との間には一定の平行関 係を認め得なかつた。

5. 本実験に於ても抗原特異性のある事を認め得た。

(大久保教授の御指導, 御校閲を深く感謝致します. 本論交の要旨は第21回日本血液学会 総会に於て 発表し た. )

\section{参考 女 献}

1) 鳥居敏雄：日本化学療法学会誌, $3: 134$ (1955)

2) 岡本緩子: 日本内科学会誌, 44, 756 (1955)

3) 楠野弥与子: 関西医大誌, $8: 66$ (1956)

4) 下条順: アレルギー, $6: 11$ (1957)

5) 大久保滉：日本血液学会誌，20:168 (1958)

6) 川原福江 : 関西医大誌, $10: 266$ (1958)

7) 今西二三男 : 関西医大誌, $10: 168$ (1958)

8) Biedl u. Krous : Wien.Klin. Wochschr. $22: 363$ (1909)

9) Dean, H.R., Webb, R.A. : J. Path. \& Bact. $27: 65$ (1924)

10) Kinsell, L.W. et al. : J. Immun. $42: 23$ (1941)

-Stavitsky, A.B. et al. : J. Immun. 63 : 389 (1949) による。

11) Waksman, B. H. : J. Immun. $70: 331$ (1953)

12) 石田政男: 日血会誌 $18: 282$ (1955), $19: 238$ (1956)

13) Webb, R.A. : J. Path. \& Bact. $27: 79$ (1924)

14）正井寿英 : 菊池教授退職記念教室研究業績集（京大 第 2 内科) 393 (1956)

15) 兵頭毅久：日血会誌 $18: 325$ (1955)

16) Miescher, R., R. Straessle \& A. Miescher : Sang, 26 : 76 (1955)

17) Moeschlin, S., Meyer, H., Isroels, L.G., Tarr-Gloor, E. : Acta Haemat. $11: 73$ (1954) 
18) Favour, C.B. et al. : Proc. Soc. Exp. Biol. \& Med. 65 : 269 (1947), $67: 502$ (1948), $70: 738(1949)$, $71: 592$ (1949)

19）中山進，安部井英一：アレルギー，2:94 (1953)

20) 川原福江：関西医大誌, $8: 128$ (1956), $9: 220$ (1957)

21) Morcel, C. Besis : Annal New York Acad. Sc. 59 : 986 (1955)
22）小延知暐：日血会誌，21：767(1958)

23）宗繁夫：内科宝画, $3: 581$ (1956)

24) Widal, F. et al. : Cpt. rend. hebdom. des seances. $171: 148$ (1934)

25) Vaugham, W.T. : J. Allergy. $6: 78$ (1934)

26) Rost: 一畔柳武雄: 臨床アレルギ一, 医学费院 (195 6)より 